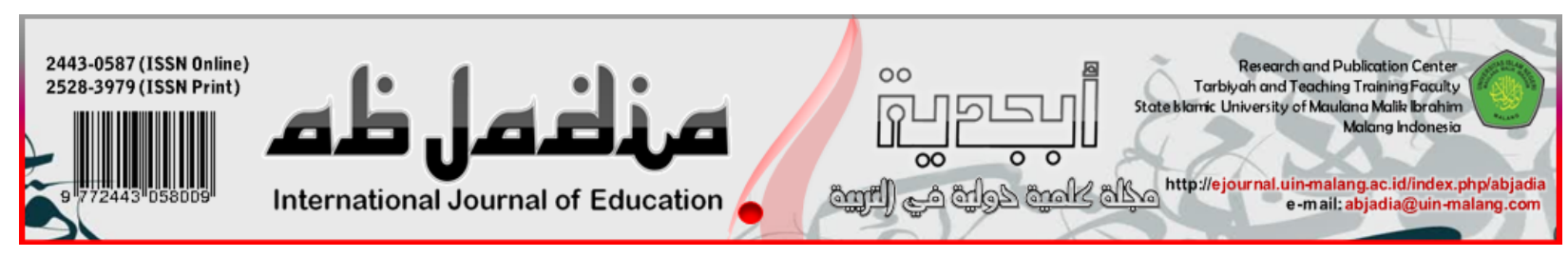

\title{
ISLAMIC CONTRIBUTION IN THE COVID-19 PANDEMIC VIEWED FROM HISTORY
}

\author{
Muhammad Efendi 1, Masriyah 2, Selamat Riadi ${ }^{3}$ \\ 1,3 Geography Study Program, FISIP, Lambung Mangkurat University \\ ${ }^{2}$ Student of PAI, FTK, UIN Antasari Banjarmasin.
}

Article History:

Received :

Revised :

Accepted :

Published : 31-12-2020

\section{Keywords:}

Pandemic, Covid-19, Islamic Contribution, History

*Correspondence Address: muhammad.efendi@ulm.ac.id

\begin{abstract}
Islam is the religion of rahmatan lil'alamin which regulates all aspects and joints of the life of the Ummah. The pattern of rules that are within the auspices of Islam actually comes from the Qur'an and Hadith. So, it can be said that the studies in the Qur'an and Hadith will always be an interesting study to be discussed in each change of age of the Ummah life, this is because every era will face different problems of life, but there are always similarities in the reasons listed in the study of the Qur'an and The Prophet's hadith. The Covid-19 outbreak that originated in Wuhan China is similar to the plague of leprosy and tha'un during the time of the Prophet Muhammad (PBUH) to His friend, which are both contagious diseases. In this paper the authors use the method of library research as a tool to explore information regarding Islam in dealing with infectious diseases. Basically, Islam has made a major contribution in dealing with all kinds of epidemics including Covid-19 which is happening in this era.
\end{abstract}

\section{(C) Introduction}

In 2020 the world was shocked by the spread of a new virus called coronavirus in a scientific language called (SARS-CoV-2) and the disease was known as Coronavirus Disease 2019 (Covid-19). This virus is known to originate from Wuhan China, was discovered at the end of December 2019. According to WHO records to date there are already 65 countries that have been exposed to the virus (SARS-CoV-2), while according to Johns Hopkins University (JHU) data, this outbreak has spread to of the 221 countries with infected patients currently at 2,062,485 (Coronavirus Live Map, 2020).

Extraordinary events by Coronavirus is not the first time. In 2002 severe acute respiratory syndrome (SARS) was spread by SARS-coronavirus (SARS-CoV) and the Middle East respiratory syndrome (MERS) disease in 2012 caused by MERS-Coronavirus (MERS-CoV) with a total accumulative case of around 10,000 (1,000 MERS cases and 8,000 SARS cases). Deaths from SARS are around $10 \%$ while MERS is higher at $40 \%$.

Covid-19 transmission is currently increasing in number every day. World Health Organization (WHO) announced the Covid-19 outbreak as a pandemic, this is because there has not been found a cure and method of transmission with certainty through 
research. An effective effort to prevent transmission that has been done in several countries is to stop the rate of outbreaks of the Covid-19 virus by locking the territory (Lockdown).

\section{$\mathbb{L}$ Theoretical Support}

Lockdown has the same meaning as isolation, things that are done at this time existed in the time of the Prophet Muhammad, although not the same disease, at that time the outbreak that occurred was leprosy, there was also the disease of Tha'un which at that time became a plague of infectious and deadly diseases, the cause comes from the bacterium Pasteurella Pestis which attacks the human body. In addition to the time of the Prophet, in the days of the Prophet's friend, Caliph Umar bin Khattab, there was also a plague that was contagious and deadly (Syauqi, 2020). This proves that the current outbreak of infectious and deadly diseases has occurred in the past. Then how did Rasulullah SAW and his companions handle the plague? This has been included in the Qur'an and Hadith as a concept of handling infectious and deadly plague.

Judging from the various diseases that have befallen humanity, Islam is based on two main sources, namely the Qur'an and Sunnah or Hadith, namely the first revelation of Allah SWT to Rasulullah SAW, while the second is what is narrated from the Prophet Muhammad in the form of his words, deeds, and confessions (pledge). Indeed, indirectly Islam has explained the form of handling of infectious disease outbreaks that is long before the SARS and MERS outbreaks especially Coronavirus, if now known as the infectious plague (Pandemic) then during the time of the Prophet until the time of friends called tha'un which has a similar meaning that is both a dangerous disease that is transmitted very quickly

\section{[Q] Method}

The method used by the authors in this paper is library research which is defined as research carried out by studying the literature and writings that have a close relationship with the problems raised in the research.

\section{†ịj Discussion}

\section{Islam's View of Disease Outbreaks from a Historical Standpoint}

\section{Leprosy}

Leprosy is a chronic disease caused by Mycobacterium Leprae infection which first attacks the peripheral nerves which can then attack the skin, oral mucosa, upper respiratory tract, reticuloendothelial system, eyes, muscles, bones, and testes, except for the central nervous system. (Zulkifli, 2003). 
Leprosy comes from the Indian language of leprosy, and in various cultures, the nation has been known since the BC era. In the Islamic tradition of leprosy or leprosy is a disease to watch out for. The Prophet Muhammad himself in a hadith teaches prayer specifically about leprosy and leprosy, namely:

$$
\begin{aligned}
& \text { وعن انس رضي الله عنه ان النبي صلى الله عليه وسلم كان يقول: اللهم إني أعوذ بك من البرص } \\
& \text { والجنون و الجذام وسي الأسقام (رواه أبو داود بإسناد الصحيح) }
\end{aligned}
$$

\section{Meaning:}

Narrated from Anas ra. That the Prophet Muhammad prayed: "O Allah, I am under your protection from stripes, crazy, leprosy, and bad diseases". (Reported by Abu Dawud with Sanad Sahih).

Lafazh-lafazh hadith mentions many of the words الجذام and البرص together because of their similar descriptions. Ibnul Manzhur in Lisanul Arab said that the meaning of albarash is a disease with a white skin profile. In the latest medical literature, it is known as an albino, which arises due to genetic processes, and is not transmitted by contact. Whereas al-judzam itself comes from the word jadzama-yadzamu which means the same meaning with qhata'a-yaqtha'u meaning to cut or cut. This hadith quote is important to know because the condition of advanced leprosy sufferers is the existence of stumped body parts without pain, especially in the hands and feet.

\section{At-Tha'un}

Ath-tha'un, some people said that the word means mass death. Some said infectious diseases that damage the air and limbs. As for other opinions say, ath-tha'un is a plague. In addition, there are also people who argue that the word means a disease that affects many people in a certain place. There are also those who say that the meaning of the word ath-tha'un is ulcers that arise from within the body, while the plague is a mass disease. Called tha'un because of its similarity to the epidemic in causing damage. Then, every tha'un it is a plague, whereas not every plague is tha'un.

It should be noted that the Islamic writers initially described tha'un is parallel with other specific diseases. The poets consider it parallel to other diseases such ashasba (measles), installments (consumption), pleurisy and miim (pleurisy), hummam (fever).

From Aisha ra. she asked the Prophet about tha'un disease. He also told him that tha'un was an adzab (torment) sent by Allah to the people He wanted, while He gave mercy to the believers. It is not a servant under siege in the tha'un plague, then he remained silent in his country in a state of patience while expecting reward and realizing that the disease would not infect him except what Allah had decreed for him, but for him the reward was like a martyr. Tha' un outbreak explained in the book of al-Isha'ah Li Ashrot al-Sa'ah written by Al-allamah al muhqaqqiq Muhammad bin Rasul al-Husaini $(1040 \mathrm{H}-1103 \mathrm{H})$ mentioned that there are five of the most dangerous tha'un in Islam, namely: (1) Tha'un syirawaih this incident at the time of the Prophet Muhammad, (2) 
Tha'un Amwas at the time of Umar bin Khattab, (3) Tha'un Al-Jarif occurred at the time Ibn Zubair, (4) Tha'un Fatayat occurred in $87 \mathrm{H}$ and (6) Tha'un al-Ashraf.

\section{Cholera Outbreak}

Cholera is an acute diarrheal disease, which is caused by an intestinal infection due to exposure to the bacterium Vibrio Cholerae. Infection is usually mild or asymptomatic, but sometimes severe. Approximately 1 out of every 20 sufferers experience severe pain with symptoms of very thin diarrhea, vomiting, and cramps in the legs. For them this rapid loss of body fluids can result in dehydration and shock or a severe physiological reaction to bodily trauma if not treated with death can occur within a few hours.

According to Johnson (2004), cholera is a disease that has long been affecting humans and continues to be a problem for global public health. Transmission of cholera can be through water, food, and poor sanitation. In 2014 a total of 190,549 cholera cases were reported by WHO by 42 countries, $55 \%$ of cases came from Africa $30 \%$ from Asia, and $15 \%$ from Hispaniola. Total cases of cholera deaths were 2,231 deaths reported by 42 countries. It is estimated that there are more than 2 million and nearly one hundred thousand deaths due to cholera each year (WHO 2015). The spread of cholera must still be watched out for because of the lack of clean and healthy living behavior in some parts of the community.

In the first half of the 19th century, cities were increasingly crowded with unskilled laborers and were not supported by good sanitation governance. Cholera emerged and became a deadly plague in Europe. In 1830 and 1847 the cholera epidemic killed tens of thousands of people in Europe. Michael McCarthy in the "Abrief History Organization" noted, in response to the cholera outbreak held an international sanitation convention which was held in Paris in 1851 and was attended by 11 European countries and Turkey. Although the conference produced a definite cause of cholera, it was the first attempt of the international community (the European sphere) to discuss the problem of preventing and controlling diseases including the yellow plague.

It was only in 1892 that the international sanitation convention succeeded in formulating cholera control and five years later with a convention that discussed outbreak control. While in Europe it was still limited to conventions, shifted to America where the Pan American Health Organization (PAHO) was founded in 1902 which was then believed to be the oldest health agent in the world. Then developed into the WHO constitution which became the first intergovernmental organization to embed the word "world" in the name of the organization.

\section{SARS Outbreak}

SARS was first identified in November 2002 in Guandong Province, southern China. Within a matter of a few months, SARS spread to 37 countries in North America, South America, Europe, and Asia. These include Japan, Singapore, Canada, Vietnam, Germany, 
the United States, Taiwan, Thailand, Switzerland, Italy, Australia, and Brazil. The spread of SARS has been classified as an epidemic since it spread to the number of countries in the world in July 2003.

In general, people diagnosed with SARS experience a high fever of more than 38 degrees Celsius. Furthermore, patients will experience other symptoms such as headaches, respiratory problems, and pain throughout the body. About 10 to 20 percent of patients sentenced to SARS also experience diarrhea. After being tested positive within two to seven days, SARS patients will experience a dry cough and pneumonia.

The SARS virus is thought to originate from bat droppings which are then in contact with humans. SARS is said to be most easily transmitted through coughing or sneezing from an infected person at close range. This virus is also called can contaminate surfaces or objects so that people who touch it most likely will be infected.

\section{MERS Outbreak}

Mers is a disease caused by the CoV virus which stands for Corona Virus. So that the Mers $\mathrm{CoV}$ disease is described as Middle Eastern Respiratory Syndrome Corona Virus, the main cause of which is the Mers virus, a virus in the coronavirus group characterized by a surface-like body structure enveloped in a structure similar to a crown. Mers $\mathrm{CoB}$ is a respiratory syndrome disease caused by a corona virus that attacks the respiratory tract from mild to severe. Mers virus can cause kidney damage and pneumonia. The Mers CoV virus is a beta coronavirus that was only recognized for the first time in 2012 in Saudi Arabia. The name Mers CoV is also referred to as novel coronavirus or abbreviated as $\mathrm{nCoV}$. The Mers virus is different from the coronavirus that has been found previously which caused SARS 2002-2003.

\section{Covid-19 Plague}

Coronavirus is a large family of viruses that cause mild to severe diseases, such as common cold or colds and serious diseases such as MERS and SARS - transmission from animals to humans (zoonosis) and transmission from humans to humans is very limited. For 2019-nCoV it is still unclear how the transmission is thought to be from animal to human because the cases that emerged in Wuhan all have a history of contact with the Huanan animal market.

The SARS-CoV-2 virus is a Coronavirus, a new type that causes an epidemic, first reported in Wuhan China on December 31, 2019. Analysis of isolates from the respiratory tract under the patient revealed the discovery of a new type of Coronavirus, named by WHO COVID-19. On 11 February 2020, WHO named the disease Coronavirus Disease 2019 (COVID-19). This new type of Coronavirus is the seventh type known in humans. SARS-CoV-2 is classified in the genus Coronavirus beta. 5.18 On January 10, 2020, the first sequencing of the SARS-CoV-2 genome was identified with 5 subsequences of viral genome sequences released. Genome sequences of the new Coronavirus (SARS-CoV-2) 
are known to be almost similar to SARS-CoV and MERS-CoV. The evolutionary tree is the same as SARS-CoV and MERS-CoV but not exactly the same.

\section{Islamic Contribution}

Management of Disease Outbreaks in Islamic Review Prophet Muhammad SAW. Aside from being a religious leader, he was also the Head of State at the time, so that all world affairs and matters relating to the interests of the afterlife became a guideline for his people until now. Therefore, the Prophet Muhammad. always be the role model of the Muslim Ummah both in the world and in the hereafter, from simple to complex things. This is appropriate with the word of Allah, which reads: (Surat al-Ahzab: 21)

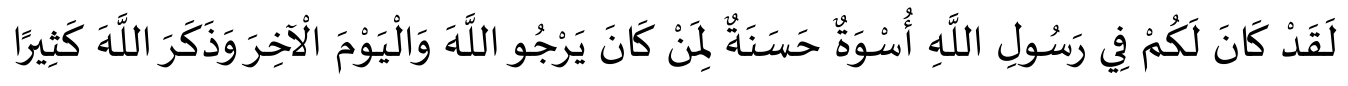

\section{Meaning:}

Indeed, the Prophet himself has set a good role model for you (that is) for those who expect (grace) Allah and (coming) the Day of Judgment and he calls more to Allah.

When talking about outbreaks or infectious diseases, they are not known only at this time, long before there were outbreaks of diseases such as SARS, Mers, Cholera, and Covid-19. During the time of the Prophet it has been known tha'un and Leprosy. Based on this history, Islam has contributed to the handling of disease outbreaks that are very relevant to be used until now, such as the handling of the Covid-19 outbreak, to prevent contracting outbreaks of disease that have been suspended in Islamic teachings and practiced by the current government, among others:

\section{Social Distancing}

Social distance or social distancing is people are asked to avoid attending large gatherings or crowds of people. Social distancing can also be interpreted as restrictions for controlling non-infectious infections or slowing the spread of an infectious disease. This is appropriate with the words of the Prophet. Regarding the handling of leprosy so that it is not contagious, namely as follows, the Prophet said:

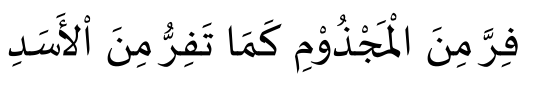

\section{Meaning:}

"Avoid you from those affected by judzam (leprosy), as you flee from the fierce lion" (HR Al-Bukhari).

If included in the science of Usul Fiqh between Leprosy, Sars, Mers and Covid-19 can be categorized as qiyas problems. Qiyas always revolves around the discussion of 'illat as the main core. Because with 'illat is a text can be expanded "area of validity" by making the law apply to other similar events so that it can accommodate as many events as possible. Al-Bukhari's hadith above explains that the Prophet Muhammad. Telling Muslims to avoid people affected by leprosy because this disease is contagious. Based on 
this, it is clearly illustrated that one form of prevention and treatment of leprosy is to keep a distance/avoid people affected by the disease. Maintaining distance/avoiding other people is the meaning of the definition of (social distancing) itself. Leprosy, Sars, Mers and COVID-19 have one 'illat (cause) in common namely infectious plague. In the hadith the Prophet Muhammad PBUH. It also likens a form of avoidance such as running away from a lion in the sense that the Ummah is aware that the plague is very dangerous and does not approach people who are affected by the infectious disease.

\section{Lockdown}

Lockdown is a term taken from English which means to lock. In the sense of lockdown is locking all access into and out of and from an area. This is following the words of the Prophet Muhammad PBUH namely:

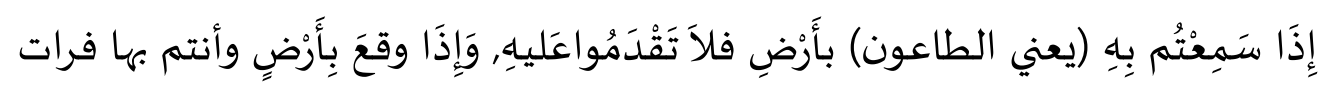

\section{Meaning:}

If you hear of an epidemic in an area, then do not enter it. But if there is an epidemic where you are, then don't leave that place. (Bukhari HR).

Based on the above hadith, it can be understood that the lockdown was in the time of the Prophet Muhammad PBUH as a form of prevention from infectious outbreaks, and now reapplied to epidemics as in the handling of Covid-19 is applied by several countries. In Usul Fiqh, it is included in the qiyas category which always looks at 'illat (cause). In the hadith above the Prophet Muhammad PBUH asked to people who hear an outbreak come to an area so they don't enter the area. Otherwise, if the plague is in our place, then we are encouraged to stay and not leave the place. Then what becomes illat in this problem is the plague. Similarly, covid-19 which became 'illat (cause) is a contagious disease. So it can concluded that handling Cvid-19 by is exactly the same as what was taught by the Prophet Muhammad PBUH in the past.

\section{Maintain cleanliness}

As a form of prevention and treatment of a disease, hygiene is always considered. Remembering a healthy lifestyle usually comes from maintaining cleanliness and vice versa because of the disease caused by lack of maintaining cleanliness. The hadith of the Prophet Muhammad PBUH regarding purification as follows:

$$
\begin{aligned}
& \text { عن أبي مالك الحارث ابن عاصهم الأشعري- رضي الله عنه - قال رسول الله صلى الله عليه } \\
& \text { وسلم: الطهور شطر الإيمان, والحمد لله تملأ الميزان, وسبحان الله و الحمد لله تملأ - أو تملآن } \\
& \text { - ما بين السمآء و اللأرض, والصلأة نور, والصيدقة برهان , والصبر ضياء, والقرآن حجة لك أو } \\
& \text { عليك, كل الناس يغدو فبائع نفسه فمعتقها أو موبقها. (رواه مسلم) }
\end{aligned}
$$




\section{Meaning:}

From Abu Malik Al-Harist bin 'Ashim Al-Ash'ari ra, Rasulullah SAW. Said: "Purification in part from the faith, Al-Hamdulillah can fill the scales, Subhanallah and Alhamdulillah can fulfill between heaven and earth, prayer is light, alms is evidence, patience is light and the Qur' an can be a witness that lightens you or burdens you. All human beings set out to sell themselves, some are who free themselves (from humiliation and punishment) and others who destroy themselves. (Muslim HR)

Based on these traditions, it can be seen that the teachings of Islam have long paid attention to maintaining cleanliness. Which includes all aspects are washing hands, cleaning the residence and others which are now called health protocols. Even in Islam, maintaining cleanliness is positioned as a form of one's faith.

\section{递 Conclusion}

Long before the existence of WHO governance or all forms of health protocols, in the teachings of Islam, it was already contributing that can be seen from the hadith which when examined in harmony with current health protocols in dealing with epidemics, such as social distancing, lockdown, and maintaining health. All of that was actually done at the time of the Prophet Muhammad PBUH. This is revealed by the qiyas method in Usul Fiqh, where in the method looks at the similarity of 'illat.

\section{Bibliography}

Al-Qahthani, Sa'id bin Ali bin Wahf. Encyclopedia of Salat, p.197.

Al-Jahiz, Hayawan, III, 78, 481; Ibn Sa'd, VII, I, 42; Abu'l Faraj al-Ishbahani (died. 356/967), Kitab al-aghani, (Cairo 1285 H), XVIII, 46; al-Tha'alibi, laa'if al-ma'arif, p. 182. See. Al-Masudi, Muruj Al-Dhahab, III, 214; al-Akhtal (wafat.93/710), Diwan, ed. Antoine Salihani (Beirut 1890).

Al-Qardhawi, Yusuf, Madakhil Li-Dirasah Al-Syari'ah Al-Islamiyah, (Al-Qahirah: Maktabah Wahbah, 1990).

Arifin, T., Nuraeni, N., Mashudi, D., \& Saefudin, E. (2020). Proteksi diri saat pandemi COVID-19 berdasarkan hadits shahih.

Az-Zuhaili, Tafsir al-Munir, Beirut: Darul Fikr, tth, p. 219

Bustomi, J., Sanah, S., \& Siregar, Z. U. (2020). Menyikapi wabah penyakit Covid-19 dalam bertasawuf.

Coronavirus Live Map, based on Live Stream Stats, Updates, Graphs, World Maps \& Count (Data taken April 15, 2020. At 11:34)

Department of Health and Human Services Centers for Disease Control and Prevention Safer-Healthier-People. H. 1-2. 
Hasballah, Z. (2020). Pandangan Agama Islam Dalam Menghadapi Wabah Covid 19 Dan New Normal.

Hidayat, Ustadz Adi. (2020). Verses of the Qur'an and the Hadith of the Prophet About Handling Plague Jakarta: Balai Pustaka (accessed from https:// youtu.be/oFS_JenHok 15 April 2020)

Imam An-Nawawi, Matan Hadith Arba'in, Translated by the Kamil Insan Team, (Solo: Insan Kamil), p. 33.

Karim, Muhammad, Lima Plague Tha'un in Islamic History, Hidayatullah.com

Kumalawati, R., Riadi, S., \& Febriyan, G. M. S. (2020). Pemanfaatan Data Geospasial dalam Proses Pembelajaran Geografi Pada Kondisi Bencana Covid-19. Jurnal Geografika (Geografi Lingkungan Lahan Basah), 1(1), 20-29.

Mahmuddin, R., \& Syandri, S. (2020). Qadariyah, Jabariyah dan Ahlus Sunnah (Studi Komparatif Merespon Kebijakan Pemerintah dan Ulama Mencegah Merebaknya Covid19). BUSTANUL FUQAHA: Jurnal Bidang Hukum Islam, 1(2), 209-222.

Maisura et al., Stochastic Model for Spread of Cholera Disease, p. 33.

Mushodiq, M. A., \& Imron, A. (2020). Peran Majelis Ulama Indonesia Dalam Mitigasi Pandemi Covid-19 (Tinjauan Tindakan Sosial dan Dominasi Kekuasaan Max Weber). SALAM: Jurnal Sosial dan Budaya Syar-i, 7(5), 455-472.

NU Online, Leprosy in Fiqh and Medical Review, accessed Thursday, April 16, 2020, Pkl. 23:00.

Ramli, Ahmad. (1968). Rules For Maintaining the Mystery of the Greatness of the Qur'an,

Riadi, S., Normelani, E. N., Efendi, M., Safitri, I., \& Tsabita, G. F. I. (2020). Persepsi Mahasiswa Prodi S1 Geografi FISIP ULM Terhadap Kuliah Online Di Masa Pandemi Covid-19. PADARINGAN (Jurnal Pendidikan Sosiologi Antropologi), 2(2), 219-227.

Rifa'i, I., Irwansyah, F. S., Sholihah, M. A., \& Yuliawati, A. (2020). Dampak dan pencegahan wabah Covid-19: Perspektif Sains dan Islam. Jurnal Lembaga Penelitian dan Pengabdian Masyarakat (LP2M).

Tabi'in, A. (2020). Perilaku Hidup Bersih dan Sehat (PHBS) pada Anak Usia Dini sebagai Upaya Pencegahan Covid 19. JEA (Jurnal Edukasi AUD), 6(1), 58-73.

Tohirin. (2013). Qualitative Research Methods in Counseling Education and Guidance. Jakarta: PT Raja Grafindo Persada.

WHO (World Health Organization), March 1 2020, PDPI, 2020.

Yunus, N. R., \& Rezki, A. (2020). Kebijakan Pemberlakuan Lock Down Sebagai Antisipasi Penyebaran Corona Virus Covid-19. Salam: Jurnal Sosial dan Budaya Syar-i, 7(3), 227238.

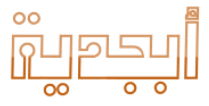

